\title{
Effect of Ruminal Incubation on Perennial Pepperweed Germination
}

\author{
Michael F. Carpinelli, ${ }^{1}$ Christopher S. Schauer, ${ }^{2}$ David W. Bohnert, ${ }^{3}$ \\ Stuart P. Hardegree, ${ }^{4}$ Stephanie J. Falck, ${ }^{5}$ and Tony J. Svejcar ${ }^{6}$ \\ Authors are ${ }^{1}$ former Rangeland Scientist, USDA-ARS, Eastern Oregon Agricultural Research Center, 67826-A Hwy 205, Burns, \\ OR 97720 and current Rangeland Management Specialist, USDA-NRCS, Grants Soil Survey Office, 1041 Mesa Blvd, Suite C, \\ Grants, NM 87020; ${ }^{2}$ Postdoctoral Research Associate, North Dakota State University, Hettinger Research Extension Center, \\ PO Box 1377, Hettinger, ND 58639-1377; ${ }^{3}$ Ruminant Nutritionist, Oregon State University, Eastern Oregon Agricultural \\ Research Center, 67826-A Hwy 205, Burns, OR 97720; ${ }^{4}$ Research Leader, USDA-ARS, Northwest Watershed Research Center, \\ 800 Park Blvd, Suite 105, Boise, ID 83712-7716; and ${ }^{5}$ Biological Research Technician and ${ }^{6}$ Research Leader, USDA-ARS, \\ Eastern Oregon Agricultural Research Center, 67826-A Hwy 205, Burns, OR 97720.
}

\begin{abstract}
Perennial pepperweed (Lepidium latifolium L.) is an aggressive perennial forb that is infesting much of western North America. Grazing may provide an alternative to chemical and mechanical control of perennial pepperweed. However, if livestock are used in control efforts, they may spread weeds by depositing viable seeds in fecal pats in uninfested areas. This study consisted of 2 experiments using fistulated steers to estimate the effect of ruminant digestion on germination of perennial pepperweed seeds. In Experiment 1, we tested the hypothesis that ruminal incubation (for 0, 48, and 96 hours) affects perennial pepperweed germination. In Experiment 2, we tested the hypothesis that type of incubation (no incubation, water only, or total digestive tract) affects perennial pepperweed germination. In Experiment 1, germination was 17 and 15 times greater for the 48 and 96-hour incubation treatments compared to the control, respectively. In Experiment 2, germination was 23 and 19 times greater for the water and total tract incubation treatments compared to the control, respectively. Effects were attributed to a combination of seed hydration and seed coat scarification. Results from this study suggest that grazing should occur prior to seed set or that livestock which have grazed perennial pepperweed bearing viable seed should be quarantined before being moved to uninfested areas. These results also suggest that control of perennial pepperweed is especially important where moving water may transport seeds off site.
\end{abstract}

\section{Resumen}

El "Perennial pepperweed" (Lepidium latifolium L.) es una hierba perenne agresiva que esta infestando muchas áreas de Norteamérica. El apacentamiento puede ser una alternativa del control químico y mecánico del "Perennial pepperweed," sin embargo, si el ganado es usado para el control de malezas, este puede dispersar semillas de ellas al depositar en áreas sin infestar heces fecales conteniendo semillas viables de malezas. Este estudio consistió de dos experimentos usando novillos fistulados para estimar el efecto de la digestión ruminal en la germinación de semillas de "Perennial pepperweed." En el experimento 1 probamos la hipótesis que la incubación ruminal (0, 48, y 96 hora) afecta la germinación de las semillas de "Perennial pepperweed" y en el experimento 2 probamos la hipótesis de que el tipo de incubación (sin incubar, solo agua y el paso, a través del tracto digestivo) también afecta la germinación de las semillas de esta especie. En el experimento 1, a las 48 y 96 horas, la germinación fue 17 y 15 veces mayor que la del control respectivamente. En el experimento 2, la germinación fue 23 y 19 veces mayor para los tratamientos de agua y paso a través del tracto digestivo, respectivamente, en comparación con el tratamiento control. Los efectos fueron a atribuidos a una combinación de hidratación de la semilla y la escarificación de la cubierta de ella. Los resultados de este estudio sugieren que el apacentamiento puede ocurrir antes de la producción de semilla o que el ganado que ha apacentado el "Perennial pepperweed," y tiene semillas viables en el tracto digestivo, debe ser cuarentenado antes de ser movido a áreas sin infestar. Estos resultados también sugieren que el control del "Perennial pepperweed" es especialmente importante donde las aguas en movimiento puede transportar las semillas de esta especie fuera de sitios infestados.

Key Words: Lepidium latifolium, selective grazing, seed hydration, seed dispersal, scarification, digestion

\section{INTRODUCTION}

The Eastern Oregon Agricultural Research Center is jointly operated by the US Dept of Agriculture-Agricultural Research Service and the Oregon State University Agricultural Experiment Station.

Correspondence: Michael F. Carpinelli, USDA-NRCS, 1041 Mesa Blvd, Suite C, Grants, NM 87020. Email: carpinelli_michael@yahoo.com

Manuscript received 10 November 2004; manuscript accepted 9 August 2005.
Perennial pepperweed (Lepidium latifolium L.) is native to southeastern Europe and western Asia. It is an herbaceous, perennial forb in the mustard family (Brassicaceae) that is infesting riparian areas, irrigation ditches, and flood meadows in much of the western portions of Canada, Mexico, and the United States. Perennial pepperweed spreads by a creeping root 
system and is a prolific seed producer. Although perennial pepperweed prefers seasonally flooded habitats, it is also capable of invading adjacent rangeland (Young et al. 1995).

Herbicides provide short-term control of perennial pepperweed, but the most effective herbicides are restricted to nonriparian areas (Sebastian et al. 1989; Reid et al. 1999; Renz 2002). Mowing and sheep grazing have been shown to reduce perennial pepperweed density and standing crop for up to 1 year after treatment (Allen et al. 2001). Although cattle, sheep, and goats will graze perennial pepperweed before, during, and after flowering (Carpinelli et al. unpublished data, 2003), impacts of long-term grazing by any species are unknown. It is possible that long-term, repeated grazing may be used to control perennial pepperweed. Livestock may be especially effective in areas that are inappropriate for mechanical or chemical control due to lack of arability or proximity to water. However, if livestock are used in control efforts, they may spread weeds by depositing viable seeds in fecal pats in uninfested areas.

The nature (positive or negative) and degree of the effect of ruminant digestion on seed germination is dependent on the species of seed (Atkeson et al. 1934; Harmon and Keim 1934; Lehrer and Tisdale 1956; Ozer 1979; Blackshaw and Rode 1991; Lyon et al. 1992; Peinetti et al. 1993; Lowry 1996; Gökbulak 2002; Schauer et al. 2004). The objective of this study was to determine the effect of ruminant digestion on germination of perennial pepperweed seeds by testing germination after simulated digestion by cattle using a combination of in situ and in vitro techniques (Tilley and Terry 1963).

This study consisted of 2 experiments. In Experiment 1, we tested the hypothesis that ruminal incubation (for 0,48 , and 96 hours) affects perennial pepperweed germination. In Experiment 2, we tested the hypothesis that type of incubation (no incubation, water only, or total digestive tract) affects perennial pepperweed germination.

\section{MATERIALS AND METHODS}

Perennial pepperweed seeds (herein called "seeds" unless otherwise specified) for both experiments were collected on the Malheur National Wildlife Refuge (UTM 11 349565E $4789765 \mathrm{~N}), 32 \mathrm{~km}$ south of Burns, Oregon, in summer 2001. Seeds were collected from 5 locations within an area $58 \mathrm{~km}$ in diameter. Seeds from all 5 locations were pooled and stored at about $22^{\circ} \mathrm{C}$ and $10 \%$ relative humidity before experimental treatment. Experimental treatments were applied in JanuaryFebruary 2002 and June-July 2002 for Experiments 1 and 2 , respectively.

Steers in Experiments 1 and 2 were offered meadow hay ( $7 \%$ crude protein; dry matter basis) harvested from flood meadows consisting of approximately $82 \%$ meadow foxtail (Alopecurus pratensis L.), with the majority of the remaining vegetation consisting of rushes (Juncus spp.), sedges (Carex spp.), and blue wildrye (Elymus glaucus Buckl.) (Wenick 2000). Hay was provided daily ( 0800 hours) at $120 \%$ of the average intake for the previous 5 days, with feed refusals from the previous day determined before feeding. A trace mineralized salt mix was available free choice $(7.3 \% \mathrm{Ca}, 7.2 \% \mathrm{P}, 27.8 \%$
$\mathrm{Na}, 23.1 \% \mathrm{Cl}, 1.5 \% \mathrm{~K}, 1.7 \% \mathrm{Mg}, 0.5 \% \mathrm{~S}, 2307$ ppm Mn, 3034 ppm Fe, 1340 ppm Cu, 3202 ppm Zn, 32 ppm Co, 78 ppm I, 85 ppm Se, 79 IU/kg vitamin E, and $397 \mathrm{kIU} / \mathrm{kg}$ vitamin A).

\section{Experiment 1}

We compared the germination of untreated (control) seeds, and seeds ruminally incubated for 48 or 96 hours $(750$ seeds per treatment) using a mobile bag technique (de Boer et al. 1987). Before the 48- and 96-hour incubation treatments, seeds were placed in nylon bags $(5 \times 10 \mathrm{~cm} ; 53 \mu \mathrm{m}$ pore size; 30 seeds/bag) and heat-sealed (de Boer et al. 1987). Two nylon nets $(40 \times 40$ $\mathrm{cm}, 5 \mathrm{~mm}$ pore size, zipper closure) were placed in the rumen of each of 5 ruminally cannulated steers $(450 \pm 50 \mathrm{~kg}): 1$ net containing five 30-seed subsamples for the 48-hour treatment and 1 net containing five 30-seed subsamples for the 96-hour treatment. There were 5 replicates per treatment, with each steer serving as a replicate for the 48- and 96-hour treatments simultaneously. The nets were placed in the rumen in reverse order (96-hour bags first, 48-hour bags 2 days later) so as to allow all nets to be removed from the rumen at the same time. Upon removal, all bags were rinsed with warm water until the effluent was clear. Bags were dried for 24 hours at $22^{\circ} \mathrm{C}$; seeds were then removed from bags and placed in coin envelopes (24-pound brown kraft stock, $2.25 \times 3.5$ inches).

Each 30-seed subsample (including twenty-five 30-seed subsamples from the untreated control) was placed on a germination cup $(50 \mathrm{~mm}$ diameter $\times 85 \mathrm{~mm}$ height, transparent snap-top vial; Thornton Plastics, Salt Lake City, UT) with a cellulose membrane in contact with the cup's solution reservoir containing $65 \mathrm{~mL}$ of polyethylene glycol solution (PEG 8000; Union Carbide Corp., Danbury, CT) to maintain a constant water potential of $-0.03 \mathrm{MPa}$ (as described in Hardegree and Emmerich 1992), dusted with Daconil ${ }^{\circledR}$ chlorothalonil fungicide (2,4,5,6-tetrachloro-1,3-benzenedicarbonitrile, wettable powder), and placed in a controlled temperature chamber for 12 days at $2^{\circ} \mathrm{C}$ (stratification) followed by 9 days at $22^{\circ} \mathrm{C}$ (typical diurnal spring temperature of seed collection site). Once germination under stratification conditions appeared to cease, the temperature was raised and maintained at the higher temperature until no further germination seemed likely. The chamber was illuminated by incandescent and fluorescent lights on a 12-hour photoperiod. Mean irradiance, measured with a radiometer placed in the center of the chamber, was $18.8 \mathrm{~W} \cdot \mathrm{m}^{-2}$. Seeds were examined, and germinants were counted and removed on a daily basis over the 21day period. A seed was considered germinated when radicle length reached $2 \mathrm{~mm}$.

\section{Experiment 2}

We compared the germination of untreated (control) seeds, seeds incubated in water for 48 hours, and seeds digested in the total gastrointestinal tract of steers (600 seeds per treatment). Before incubation, sixteen 75 -seed subsamples were placed in nylon bags $(2.5 \times 5 \mathrm{~cm} ; 53 \mu \mathrm{m}$ pore size; 75 seeds/bag $)$ and heat-sealed (de Boer et al. 1987). One nylon net $(40 \times 40 \mathrm{~cm}, 5$ $\mathrm{mm}$ pore size, zipper closure) containing two 75 -seed subsamples was placed into the rumen of each of 4 ruminally and duodenally cannulated steers $(450 \pm 50 \mathrm{~kg})$. There were 4 
Experiment 1

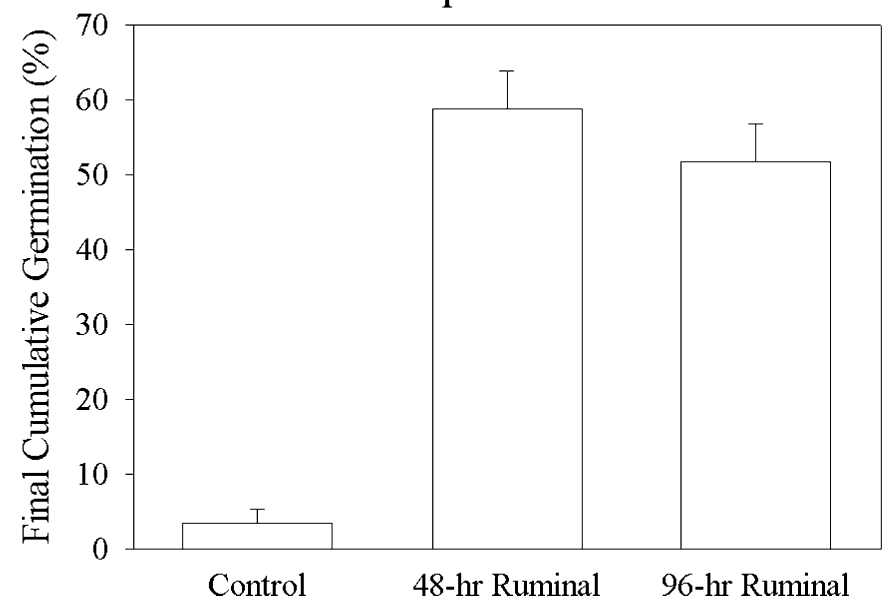

Experiment 2

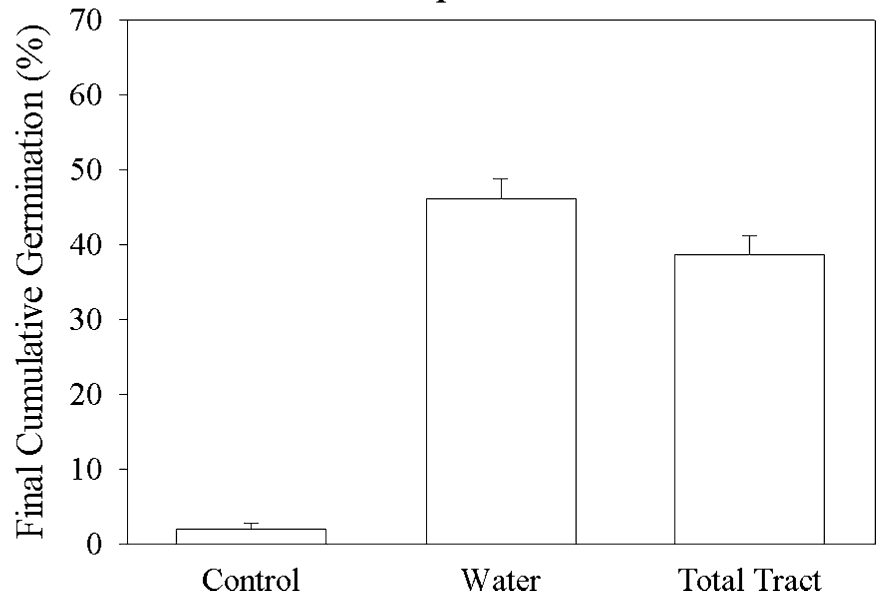

Figure 1. Final cumulative perennial pepperweed germination for Experiments 1 and 2. In Experiment 1, germination was $3.44 \%, 58.8 \%$, and $51.7 \%$ for control, 48-hour ruminal incubation, and 96-hour ruminal incubation treatments, respectively. In Experiment 2, germination was 2.01\%, 46.2\%, and $38.7 \%$ for control, water incubation, and total tract incubation treatments, respectively. Error bars $=1 \mathrm{SE}$.

replicates $(1$ steer $=1$ replicate) per treatment. After 48 hours of ruminal incubation, the nets were removed from the rumen, and the bags were rinsed with warm water to remove particulate matter and placed in a pepsin solution $(0.1 \% \mathrm{wt} /$ vol pepsin [Sigma P-7012]; 10\% vol/vol $1 \mathrm{~N} \mathrm{HCl}$; remaining volume, distilled $\mathrm{H}_{2} \mathrm{O}$ ) in an Ankom ${ }^{\circledR}$ Daisy II incubator at $39^{\circ} \mathrm{C}$ for 2 hours (with agitation) to mimic abomasal digestion (Berthiaume et al. 2000). Following simulated abomasal digestion, the nylon bags were rinsed and inserted into the duodenal cannulae at 30-minute intervals. Within 20 hours of duodenal insertion, all nylon bags were excreted in feces and collected. Bags were rinsed with warm water to remove fecal matter and dried for 24 hours at $22^{\circ} \mathrm{C}$, after which time the seeds from each replication were removed from bags and placed in coin envelopes (30 seeds/envelope). For the water-incubation treatment, eight 75 -seed subsamples $(2$ subsamples per replication) were incubated in distilled water at $39^{\circ} \mathrm{C}$ in an $A n k o m{ }^{\circledR}$ Daisy II incubator for 48 hours (with agitation) and dried for 24 hours at $22^{\circ} \mathrm{C}$; seeds from each replication were then removed from bags and placed in coin envelopes (30 seeds/ envelope).

All seeds (including twenty 30-seed subsamples from the untreated control) were treated as in Experiment 1 (germination cup, fungicide) and placed in a controlled temperature chamber for 56 days at $3^{\circ} \mathrm{C}$ (stratification) followed by 7 days at $22^{\circ} \mathrm{C}$ (typical diurnal spring temperature of seed collection site). Once germination under stratification conditions appeared to cease, the temperature was raised and maintained at the higher temperature until no further germination seemed likely. Chamber irradiance was as described for Experiment 1. Seeds were examined, and germinants were counted and removed on a daily basis over the 63-day period. A seed was considered germinated when radicle length reached $2 \mathrm{~mm}$.

\section{Statistical Analysis}

Data were analyzed as a randomized complete block with subsampling $\quad$ (steers $=$ random effect; steers by treat- ment $=$ random effect; treatment $=$ fixed effect $).$ Data were transformed to stabilize the variances among treatments using the arcsine square root transformation. Means were separated using Student's $t$ tests $(P<0.05)$.

\section{RESULTS AND DISCUSSION}

In Experiment 1, final cumulative germination was 17 $(P<0.01)$ and $15(P<0.01)$ times greater for the 48 - and 96-hour incubation treatments compared to the control, respectively (Fig. 1). The 48- and 96-hour incubation treatments were similar $(P=0.61)$. In Experiment 2, final cumulative germination was $23(P<0.01)$ and $19(P<0.01)$ times greater for the water and total tract incubation treatments compared to the control, respectively (Fig. 1). The water and total tract incubation treatments were similar $(P=0.19)$. In both experiments, cumulative germination was minimal before temperature elevation (Fig. 2).

The increase in germination under incubation treatments in both experiments may have resulted from seed hydration or scarification, or both. Apparently, seed hydration was not enhanced beyond 48 hours of ruminal incubation (Experiment 1) because the effects of 48- and 96-hour ruminal incubation treatments were similar. Similar germination for the water and total tract incubation treatments (Experiment 2) suggests seed hydration effects were not influenced by type of incubation (water vs. total tract). Osmotic conditioning-or priming-is a presowing seed treatment intended to increase germination rate through controlled hydration (allowing for pregerminative metabolism without radicle extension), followed by hardening-a drying period that "fixes" this invigorative effect (Hanson 1973; Bradford 1986). The incubation and drying treatments in Experiments 1 and 2 may have, in effect, primed the perennial pepperweed seeds.

Both physical scarification (mastication, ruminal contractions, peristalsis) and chemical scarification (acidic and enzymatic conditions in the digestive environment) may contribute 
Experiment 1

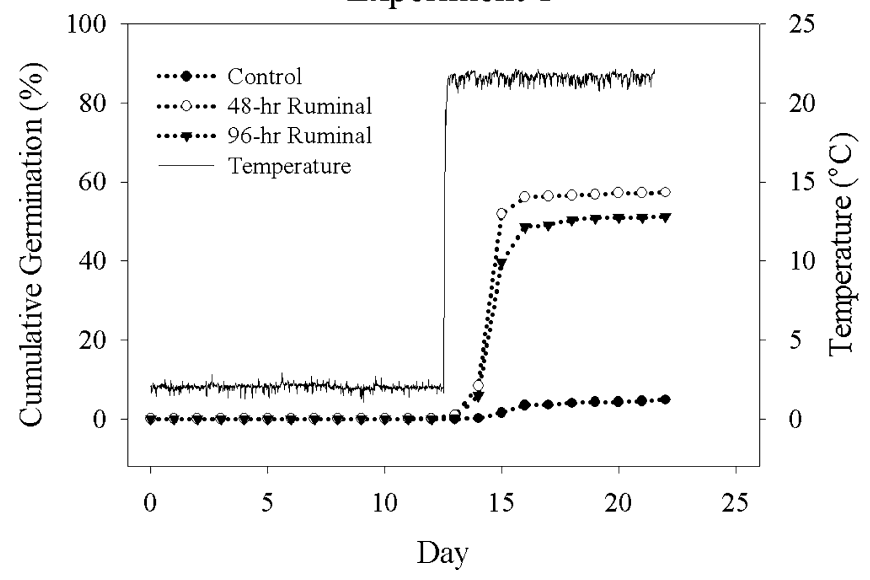

Experiment 2

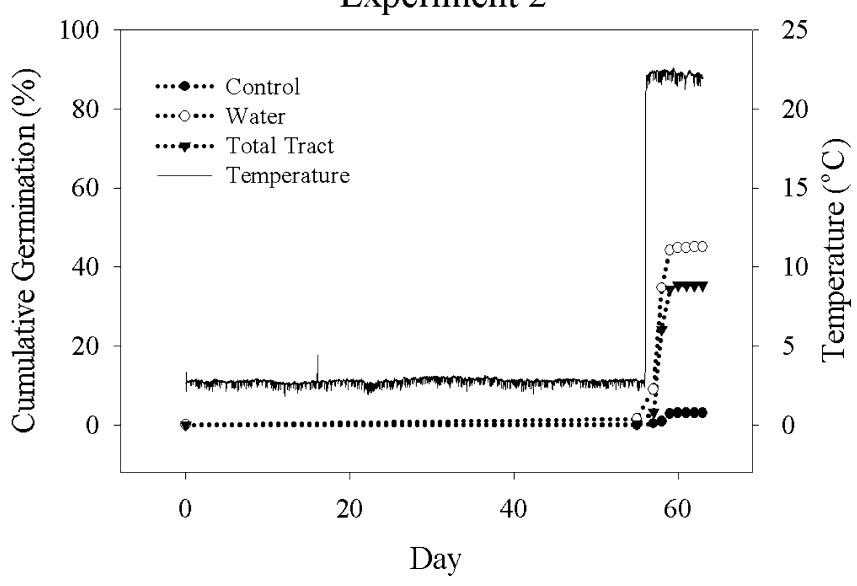

Figure 2. Cumulative perennial pepperweed germination (expressed as the percentage of total seeds per treatment) and chamber temperature for Experiments 1 and 2.

to increased germination in some hard-coated seeds following ingestion by livestock. Hoary cress (Cardaria draba [L.] Desv.), formerly classified as a congener of perennial pepperweed and bearing small, hard-coated seeds, increased germination 2.8 and 3.2 times after ingestion and passage by cattle and sheep, respectively (Harmon and Keim 1934). Germination following ruminal incubation was 1.8 times higher for field pennycress (Thlaspi arvense L.) (Blackshaw and Rode 1991), another member of the mustard family with small, hard-coated seeds (NAPPO 2003). Ocumpaugh et al. (1995) suggest seed dormancy may enhance seed viability after passage through the digestive system of cattle. Perennial pepperweed seeds do not appear to have an inherent dormancy system (e.g., hard seed coat) (Miller et al. 1986), so it remains possible that any benefit from scarification may be outweighed by seed degradation. In this study however, it appeared the net combined effect of hydration and scarification increased germination.

Prolonged exposure to the ruminant digestive environment degrades the seed coat of some species, especially species with a soft seed coat, to the point at which germinability eventually decreases (Blackshaw and Rode 1991; Schauer et al. 2004). In this study, seed coat degradation was likely minimal, as evidenced by the similar germination between the 48- and 96hour ruminal incubation treatments (Experiment 1) and the similar germination between the water incubation and total tract incubation treatments (Experiment 2).

Typical total residence time in the digestive tract of a cow from ingestion to defecation follows a Poisson-like distribution with most passage occurring within 1 to 3 days; however, passage can take up to 7 days or more (Poppi et al. 2001). Following natural ingestion, residence time in the alimentary canal may be relatively high for the buoyant seeds (specific gravity $<1.0$ ) of perennial pepperweed. Gardener et al. (1993) found that of 18 species of grasses and legumes tested, only 4 had a specific gravity $<1.0$, and that specific gravity had a positive effect on rate of passage through the cattle digestive system. However, reduced germination of perennial pepperweed caused by increased seed degradation resulting from slow passage may be offset by reduced seed damage caused by mastication (not tested here) because of its small seed size.
Akbar et al. (1995) found that about $90 \%$ of crested wheatgrass seeds fed to cattle were passed without visible signs of physical damage. Given that perennial pepperweed seeds are much smaller than crested wheatgrass seeds, perennial pepperweed seeds may be even less prone to damage from mastication. Potentially, some seeds that escape mastication may reside in the digestive tract long enough to become nongerminable, but given the variability in residence time, it is likely that at least some germinable seeds are excreted.

\section{MANAGEMENT IMPLICATIONS}

The propensity of perennial pepperweed to thrive in areas in proximity to moving water such as riparian areas, flood meadows, and irrigation ditches allows for effective off-site seed dissemination. The ability of perennial pepperweed to expand its range may be further enhanced by the potential increase in germinability from seed hydration and from the mucilage its seeds produce upon wetting (Young and Evans 1973). Mucilage potentially aids substrate attachment as well as germination under conditions of low osmotic potential (Harper 1977). Therefore, control of perennial pepperweed near moving water is especially important.

To minimize weed expansion, animals that have fed on plants bearing viable seeds of any weed species are best quarantined on weed-free forage or hay for at least 7 days before transport to non-weed-infested areas. Because of the potential increase in germination following ingestion by ruminants, this practice is key. Once seed has passed through the gastrointestinal tract and is deposited in fecal pats, germinability of some species decreases over time with some seeds still germinable after 3 months (Harmon and Keim 1934). Alternatively, germinability may increase with storage in fecal pats, as has been shown with alfalfa (Atkeson et al. 1934) and sweet clover (Harmon and Keim 1934). Akbar et al. (1995) found that favorable moisture and temperature conditions within fecal pats of cattle promoted crested wheatgrass germination. With the increasing interest in using alternative classes of livestock as weed control agents, it should be noted that 
recovery of viable pasture seed from dung of sheep and goats was found to be $50 \%$ and $25 \%$ less, respectively, than that of cattle (Simao Neto et al. 1987). However, the invasiveness and competitiveness of perennial pepperweed warrant the quarantining of any livestock that have consumed mature seed, or preferably, eliminating seed production altogether by grazing prior to seed set.

\section{ACKNOWLEDGMENTS}

The authors thank Laura May and Bruce Mackey for their valuable assistance.

\section{LITERATURE CITED}

Akbar, G., C. A. Call, and R. D. Wiedmeier. 1995. Dungpat microenvironmental effects on germination and establishment of crested wheatgrass. Arid Soil Research and Rehabilitation 9:409-422.

Allen, J. R., D. W. Holcombe, D. R. Hanks, M. Surian, M. McFarland, L. B. Bruce, W. Johnson, and G. C. J. Fernandez. 2001. Effects of sheep grazing and mowing on the control of perennial pepperweed (Lepidium latifolium L.). Proceedings of the Western Section of the American Society of Animal Science 52:317-320.

Atkeson, F. W., H. W. Hulbert, and T. R. Warren. 1934. Effect of bovine digestion and of manure storage on viability of weed seeds. Journal of the American Society of Agronomy 26:390-397.

Berthiaume, R., H. Lapierre, M. Stevenson, N. Coté, and B. W. McBride. 2000. Comparison of the in situ and in vivo intestinal disappearance of ruminally protected methionine. Journal of Dairy Science 83:2049-2056.

BLACKSHAw, R. E., AND L. M. RodE. 1991. Effect of ensiling and rumen digestion by cattle on weed seed viability. Weed Science 39:104-108.

BRADFORD, K. J. 1986. Manipulation of seed water relations via osmotic priming to improve germination under stress conditions. HortScience 21:1105-1112.

de Boer, G., J. J. Murphy, and J. J. Kennelly. 1987. A modified method for determination of in situ rumen degradation of feedstuffs. Canadian Journal of Animal Science 67:93-102.

Gardener, C. J., J. G. Mclvor, And A. Jansen. 1993. Passage of legume and grass seeds through the digestive tract of cattle and their survival in faeces. Journal of Applied Ecology 30:63-74.

GöквULAK, F. 2002. Effect of American bison (Bison bison L.) on the recovery and germinability of seeds of range forage species. Grass and Forage Science 57:395-400.

Hanson, A. D. 1973. The effects of imbibition drying treatments on wheat seeds. New Phytologist 72:1063-1073.

Hardegree S. P., and W. E. Emmerich. 1992. Effect of matric-priming duration and priming water potential on germination of four grasses. Journal of Experimental Botany 43:233-238.

Harmon, G. W., And F. D. Keim. 1934. The percentage and viability of weed seeds recovered in the feces of farm animals and their longevity when buried in manure. Journal of the American Society of Agronomy 26:762-767.
Harper, J. L. 1977. The Population Biology of Plants. Academic Press, London. 892 p.

LehreR, W. P., and E. W. TISDAlE. 1956. Effect of sheep and rabbit digestion on the viability of some range plant seeds. Journal of Range Management 9: 118-122.

LowRY, A. A. 1996. Influence of ruminant digestive processes on germination of ingested seeds [thesis]. Corvallis, OR: Oregon State University. $150 \mathrm{p}$.

Lyon D. J., D. D. Baltensperger, and I. G. Rush. 1992. Viability, germination, and emergence of cattle-fed jointed goatgrass seed. Journal of Production Agriculture 5:282-285.

Miller, G. K., J. A. Young, and R. A. Evans. 1986. Germination of seeds of perennial pepperweed (Lepidium latifolium). Weed Science 34:252-255.

[NAPP0] North American Plant Protection Organization. 2003. Grains Panel Pest Fact Sheet-Thlaspi arvense L. Ottawa, Canada: NAPPO. $11 \mathrm{p}$.

Ocumpaugh, W. R., C. R. Tischler, and L. S. Valle. 1995. Post-harvest seed dormancy effects on kleingrass germination following simulated digestion by cattle. Crop Science 35:260-263.

Ozer, Z. 1979. The influence of passage through sheep and fermentation in dung on the viability of seeds of meadow plants. Weed Research 19: 247-254.

Peinetti, R., M. Pereyra, A. Kin, and A. Sosa. 1993. Effects of cattle ingestion on viability and germination rate of caldén (Prosopis caldenia) seeds. Journal of Range Management 46:483-486.

Poppl, D. P., W. C. Ellis, J. H. Matis, and C. E. Lascano. 2001. Marker concentration patterns of labelled leaf and stem particles in the rumen of cattle grazing bermuda grass (Cynodon dactylon) analysed by reference to a raft model. British Journal of Nutrition 85:553-563.

Reid, C. R., G. A. Rasmussen, S. Dewey, and B. Kitchen. 1999. Biology and management of perennial pepperweed, a Utah prospective. Proceedings of the National Symposium on Tall Whitetop; June 9-10; Alamosa, C0. 48 p.

ReNZ, M. J. 2002. The biology, ecology and control of perennial pepperweed (Lepidium latifolium L.) [thesis]. Davis, CA: University of California. $129 \mathrm{p}$.

Schauer, C. S., D. W. Bohnert, M. F. Carpinelli, and S. J. Falck. 2004. Nutritional calendar and germination responses to ruminal incubation of forage kochia. Rangelands 26:8-11.

Sebastian, J. S., K. G. Beck, and D. E. Hanson. 1989. Perennial pepperweed control with metsulfuron, chlorosulfuron, and 2,4-D on Colorado rangeland. Research Progress Report. Newark, CA: Western Society of Weed Science. p 7-8.

Simao Neto, M., R. M. Jones, and D. Ratcliff. 1987. Recovery of pasture seed ingested by ruminants. Seed of six tropical pasture species fed to cattle, sheep and goats. Australian Journal of Experimental Agriculture 27:239-246.

Tilley, J. M. A., And R. A. Terry. 1963. A two stage technique for the in vitro digestion of forage crops. Journal of the British Grassland Society 18: 104-111.

WENICK, J. J. 2000. The effect of grazing interval on forage quality and production of meadow foxtail [thesis]. Coravallis, OR: Oregon State University. $38 \mathrm{p}$.

Young, J. A., And R. A. Evans. 1973. Mucilaginous seed coats. Weed Science 21:52-54.

Young, J. A., C. E. Turner, and L. F. James. 1995. Perennial pepperweed. Rangelands 17:121-123. 